\title{
RADIOCARBON MEASUREMENTS IN SOUTH PACIFIC OCEAN WATERS IN THE VICINITY OF THE SUBTROPICAL CONVERGENCE ZONE
}

\author{
R. J. SPARKS, G. W. DRUMMOND, G. W. BRAILSFORD, D. C. LOWE, K. R. LASSEY \\ M. R. MANNING, C. B. TAYLOR and GAVIN WALLACE
}

Nuclear Sciences Group, DSIR Physical Sciences, P. O. Box 31312, Lower Hutt, New Zealand

\begin{abstract}
Distribution profiles of radiocarbon in dissolved inorganic carbonate have been measured along two transects in the southern Pacific, east of New Zealand. Use of accelerator mass spectrometry, with its small-sample-size capability, made it possible to sample near-surface waters with a depth resolution of a few tens of meters. Sampling of deeper water was guided by salinity and temperature data transmitted by a conductivity-temperature-depth probe. The measurements, taken over the Chatham Rise, show highly structured profiles that can be correlated with known circulation patterns in this region.
\end{abstract}

\section{INTRODUCTION}

The Chatham Rise is an elevated region of the sea floor extending from the Chatham Islands westward toward the South Island of New Zealand. Its latitude $\left(44^{\circ} \mathrm{S}\right)$ corresponds approximately to that of the Subtropical Convergence (STC), the boundary between the northern subtropical waters and the cooler, less saline subantarctic waters to the south. In fact, the presence of the Chatham Rise has the effect of anchoring the STC immediately east of New Zealand to a fairly well-defined region around $44^{\circ} \mathrm{S}$. East of the Chatham Islands, the increasing depth of the sea floor reduces the effects of the Chatham Rise, and the STC moves southward, before turning north again beyond longitude $170^{\circ} \mathrm{W}$.

In addition to the STC, two other oceanic fronts have been identified that play roles in the oceanic circulation near New Zealand (Heath 1981, 1982). These are the Subantarctic Front, that separates the Circumpolar Subantarctic Water from the Australasian Subantarctic Water, and the Polar Front, that separates Circumpolar Subantarctic Water from the Antarctic Surface Water. The net result is a flow of Subantarctic Water eastward across the south Tasman Sea, with part of this flow being directed north through the Tasman Sea, and part moving south of New Zealand before turning northwards just southeast of New Zealand until it encounters the Chatham Rise (Fig. 1).

Physically, the area east of New Zealand forms a complex system. The water movement is governed by the topography of the region, with the Campbell Plateau and Bounty Islands to the south, and the Chatham Rise forming a partial barrier between the northern and southern waters. This area is of considerable economic as well as scientific interest to New Zealand and is being extensively investigated by the New Zealand Oceanographic Institute. It seemed well suited for a pilot study to determine whether measurements of the distribution of ${ }^{14} \mathrm{C}$ and tritium could provide useful information on the circulation and mixing in the region.

\section{SAMPLE COLLECTION AND PROCESSING}

The seawater samples were collected during Cruise 2013 (November 1987) and Cruise 2028 (July 1989) of the New Zealand DSIR research vessel, Rapuhia. The samples from Cruise 2013 were collected from six casts made to a maximum depth of $1000 \mathrm{~m}$ along a north-south line at longitude $179^{\circ} \mathrm{E}$, and spanning the latitude range, $41^{\circ}$ to $47^{\circ} \mathrm{S}$. Casts R326 and R327 over the Chatham Rise reached maximum depths of 600 and $350 \mathrm{~m}$, respectively, corresponding to the depth of the sea floor at these stations. Cruise 2028 provided samples from eight casts along a north-south line at longitude $177.5^{\circ} \mathrm{E}$, over a latitude range, $42.7^{\circ}$ to $46^{\circ} \mathrm{S}$. Tritium data only were measured for the 


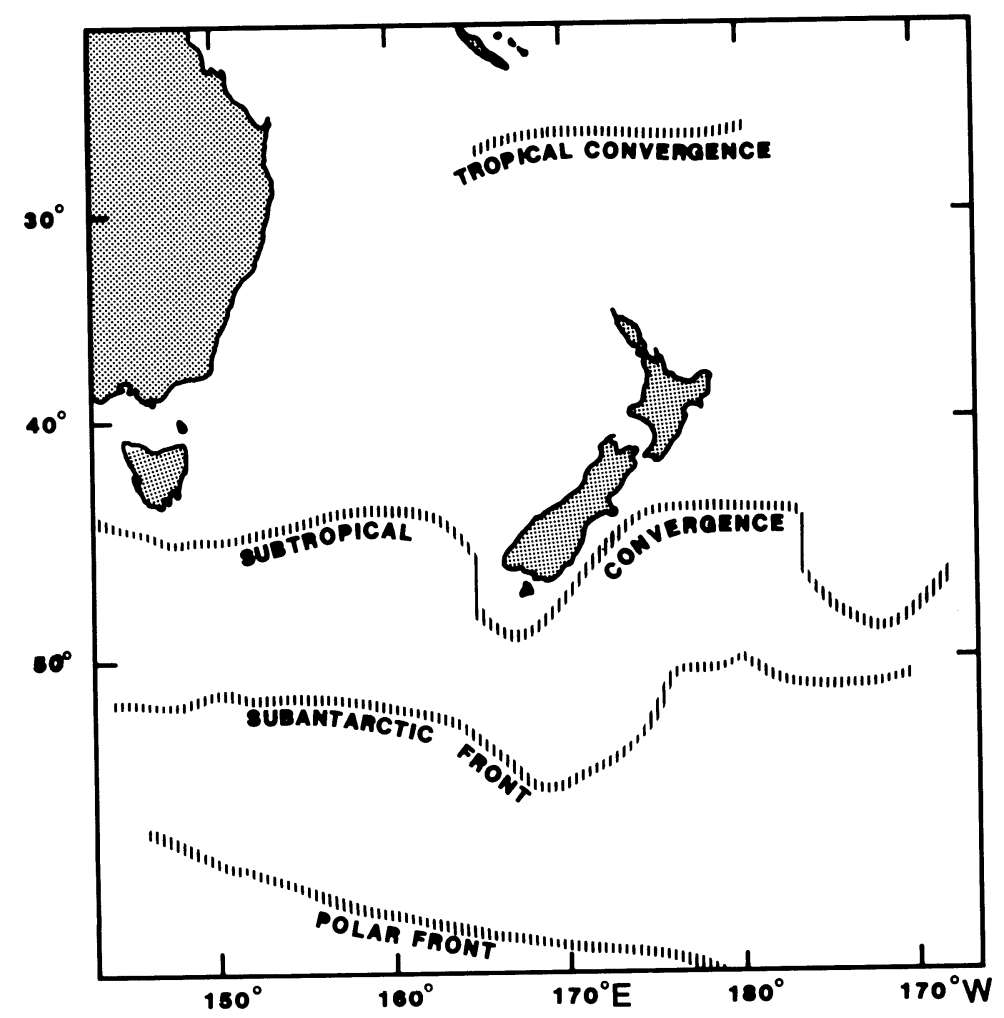

Fig. 1. Oceanic fronts around New Zealand (after Heath 1982)

cast at $44.2^{\circ}$. Samples were taken at intervals to the sea floor, which ranged from 270 to $2400 \mathrm{~m}$. The sampling stations for the two cruises are shown in Figure 2.

The water was collected in 2-liter Niskin bottles attached to a conductivity-temperature-depth (CTD) Rosette that recorded the salinity and temperature of the water. Sampling was at $c a .100-\mathrm{m}$ intervals, but the exact depths were chosen on the basis of any structure observed in the temperature and salinity profiles by monitoring the signals transmitted from the CTD probe during the cast. Each sample was split into two portions. Water for tritium analysis was stored in 1-liter glass bottles. The ${ }^{14} \mathrm{C}$ samples were stored in completely filled 500 -ml glass bottles with screw-on seals, and were poisoned with $c a .75 \mathrm{mg}$ mercuric chloride to suppress bacterial activity.

\section{Radiocarbon Sample Processing}

Preparation of samples for accelerator mass spectrometry (AMS) measurement consisted of extracting the inorganic carbon from the water as $\mathrm{CO}_{2}$ gas, and converting the $\mathrm{CO}_{2}$ to graphite for insertion in the tandem accelerator sputter ion source. The $\mathrm{CO}_{2}$ extraction was carried out by vacuum distillation of $150 \mathrm{ml}$ water acidified with $3 \mathrm{ml}$ of $14.7 \mathrm{M}$ phosphoric acid (Sparks et al. 1988). The gas evolved from the water passed through two dry-ice/alcohol traps to remove all water vapor, and the $\mathrm{CO}_{2}$ was frozen down in a liquid nitrogen trap. After further pumping to remove any volatile vapors, the $\mathrm{CO}_{2}$ was transferred to a small reaction vessel containing the ionsource sample holder, in which iron powder had already been placed, and hydrogen added. The reaction vessel was heated at $750^{\circ} \mathrm{C}$ for several hours in a furnace, during which time the $\mathrm{CO}_{2}$ was catalytically reduced to graphite over the iron powder. After the graphite was compressed in a 


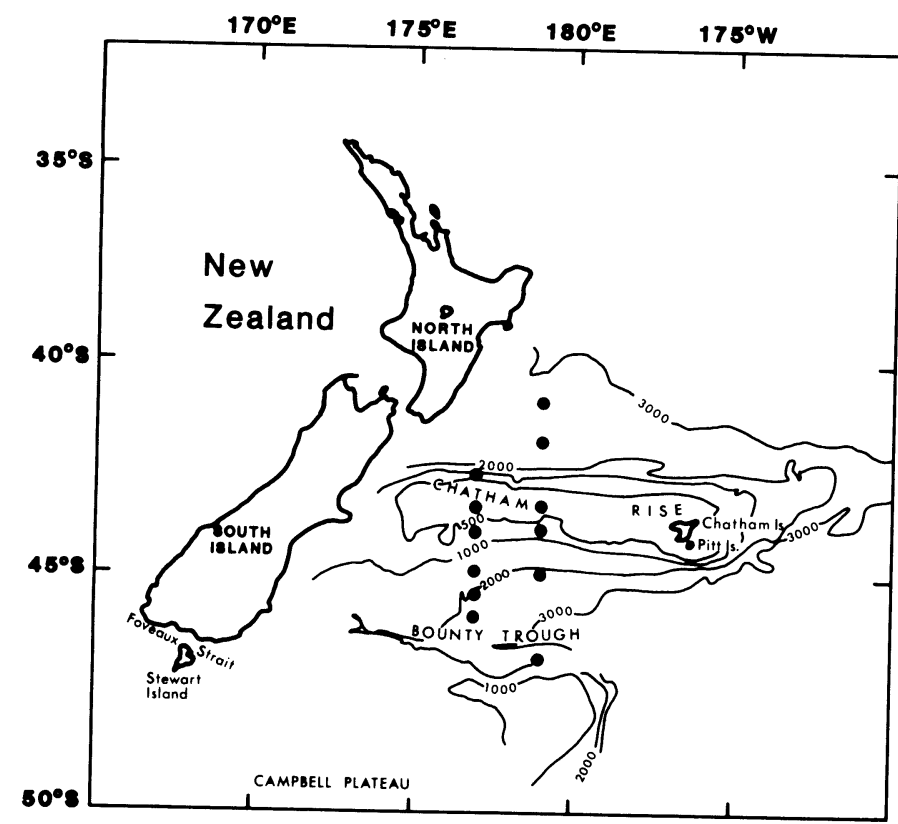

Fig. 2. Sampling locations used to obtain the data in this work. Sea-floor depth contours are labeled in meters.

press, the sample was ready for measurement on the accelerator. Using this method, it was possible to process up to six seawater samples per day. Results of the ${ }^{14} \mathrm{C}$ measurements are reported as $\Delta^{14} \mathrm{C}$ relative to the age-corrected activity of the NBS oxalic acid standard, as conventionally defined (Stuiver \& Polach 1977), and include a $\delta^{13} \mathrm{C}$ correction to $-25 \%$.

\section{Tritium}

Tritium was measured by electrolytic enrichment of the samples followed by liquid scintillation counting. Results are reported as tritium units (TU), where one TU is one tritium atom per $10^{18}$ hydrogen atoms. As indicated above, salinity and temperature data were obtained for each sample by the CTD probe during sample collection.

\section{RESUltS AND DISCUSSION}

The results for the data from Cruise 2013 are shown as contour plots for $\Delta^{14} \mathrm{C}$, tritium and salinity in Figures 3-5, respectively, and are listed in Table 1. The presence of the STC can be recognized in all the plots in the region just north of the Chatham Rise between latitudes $41^{\circ}$ and $42^{\circ} \mathrm{S}$. The isotope data, especially ${ }^{14} \mathrm{C}$, give the strongest indications of the presence of the STC, although salinity and temperature are the traditional indicators of oceanic fronts. In particular, in the extreme northern set of data at $41^{\circ} \mathrm{S}$, the ${ }^{14} \mathrm{C}$ shows a steady $\Delta{ }^{14} \mathrm{C}$ of $+150 \%$ down to $300 \mathrm{~m}$ depth, indicating complete mixing down to this depth, and the other data are consistent with this interpretation. Over the Chatham Rise itself the contour lines tend to move towards the surface, marking the transition to the Subantarctic waters to the south.

A notable feature of the ${ }^{14} \mathrm{C}$ distribution is the presence of a tongue of water at about $200 \mathrm{~m}$ deep, enhanced in ${ }^{14} \mathrm{C}$ relative to the surface waters, extending from the Chatham Rise southward to about $47^{\circ} \mathrm{S}$. Signs of the same structure can be seen in the tritium and salinity data. The presence of a high-salinity tongue extending south of the STC was discussed by Heath (1976), who described the tongue as an anomaly on an underlying smooth salinity profile, and explained it as 
TABLE 1. Data for Samples Collected on RV Rapuhia Cruise 2013, November 1987

\begin{tabular}{|c|c|c|c|c|c|}
\hline Latitude & $\begin{array}{l}\text { Depth } \\
\text { (m) }\end{array}$ & $\begin{array}{l}\Delta^{14} \mathrm{C} \\
(\%)\end{array}$ & $\begin{array}{c}\text { Tritium } \\
\text { (TU) }\end{array}$ & $\begin{array}{c}\text { Salinity } \\
(\% 0)\end{array}$ & $\begin{array}{c}\text { Temperature } \\
\left({ }^{\circ} \mathrm{C}\right)\end{array}$ \\
\hline \multirow[t]{11}{*}{$41.0^{\circ} \mathrm{S}$} & 10 & $223.8 \pm 24.0$ & $0.70 \pm 0.08$ & 35.19 & 14.6 \\
\hline & 100 & $148.7 \pm 18.8$ & $0.76 \pm 0.08$ & 35.19 & 12.9 \\
\hline & 200 & $188.2 \pm 66.7$ & $0.81 \pm 0.08$ & 35.19 & 12.9 \\
\hline & 300 & $165.3 \pm 33.3$ & $0.76 \pm 0.09$ & 35.01 & 12.0 \\
\hline & 350 & & $0.69 \pm 0.08$ & 34.93 & 11.5 \\
\hline & 400 & & $0.61 \pm 0.07$ & 34.84 & 10.9 \\
\hline & 450 & $83.3 \pm 12.5$ & & 34.80 & 10.5 \\
\hline & 500 & $30.8 \pm 8.4$ & $0.42 \pm 0.06$ & 34.73 & 9.9 \\
\hline & 600 & $31.9 \pm 9.4$ & $0.35 \pm 0.07$ & 34.63 & 8.8 \\
\hline & 800 & $-9.8 \pm 11.4$ & $0.13 \pm 0.07$ & 34.52 & 7.4 \\
\hline & 1000 & $-79.6 \pm 20.8$ & $0.08 \pm 0.07$ & 34.46 & 6.1 \\
\hline \multirow[t]{11}{*}{$42.0^{\circ} \mathrm{S}$} & 0 & $78.6 \pm 8.4$ & $0.82 \pm 0.07$ & 34.97 & 14.2 \\
\hline & 30 & $108.8 \pm 19.8$ & & 35.02 & 13.8 \\
\hline & 60 & $90.3 \pm 8.4$ & $0.60 \pm 0.08$ & 35.00 & 12.2 \\
\hline & 100 & $89.3 \pm 8.4$ & $0.73 \pm 0.08$ & 35.02 & 12.1 \\
\hline & 200 & $89.3 \pm 8.4$ & $0.77 \pm 0.07$ & 34.89 & 11.4 \\
\hline & 300 & $53.5 \pm 13.5$ & $0.58 \pm 0.08$ & 34.72 & 10.1 \\
\hline & 400 & $84.0 \pm 10.5$ & $0.47 \pm 0.07$ & 34.70 & 9.5 \\
\hline & 500 & $14.4 \pm 11.4$ & $0.40 \pm 0.10$ & 34.62 & 8.6 \\
\hline & 600 & $-5.6 \pm 19.8$ & $0.30 \pm 0.07$ & 34.56 & 8.0 \\
\hline & 800 & $-41.1 \pm 8.4$ & $0.25 \pm 0.06$ & 34.47 & 6.6 \\
\hline & 1000 & $-98.4 \pm 7.3$ & $0.15 \pm 0.06$ & 34.47 & 5.2 \\
\hline \multirow[t]{6}{*}{$43.5^{\circ} \mathrm{S}$} & 25 & & $1.08 \pm 0.08$ & 34.87 & 13.0 \\
\hline & 70 & $82.0 \pm 14.6$ & $0.61 \pm 0.07$ & 34.69 & 10.8 \\
\hline & 100 & $63.1 \pm 9.4$ & $0.64 \pm 0.07$ & 34.69 & 10.4 \\
\hline & 150 & $63.5 \pm 9.4$ & $0.54 \pm 0.07$ & 34.60 & 9.6 \\
\hline & 250 & $67.1 \pm 12.5$ & $0.54 \pm 0.07$ & 34.53 & 8.8 \\
\hline & 350 & $65.5 \pm 16.7$ & $0.54 \pm 0.08$ & 34.42 & 7.4 \\
\hline \multirow[t]{6}{*}{$44.0^{\circ} \mathrm{S}$} & 20 & $89.3 \pm 34.4$ & $0.65 \pm 0.08$ & 34.72 & 12.4 \\
\hline & 60 & $71.5 \pm 18.7$ & $0.64 \pm 0.07$ & 34.56 & 10.5 \\
\hline & 150 & $98.5 \pm 14.5$ & $0.62 \pm 0.07$ & 34.45 & 8.7 \\
\hline & 250 & $84.0 \pm 30.2$ & $0.59 \pm 0.09$ & 34.49 & 8.3 \\
\hline & 400 & $89.2 \pm 14.5$ & $0.52 \pm 0.08$ & 34.42 & 7.7 \\
\hline & 600 & $65.2 \pm 12.5$ & $0.52 \pm 0.08$ & 34.39 & 7.0 \\
\hline \multirow{8}{*}{$45.0^{\circ} \mathrm{S}$} & 20 & $18.3 \pm 18.8$ & $0.56 \pm 0.08$ & 34.49 & 11.6 \\
\hline & 50 & $97.5 \pm 20.8$ & $0.61 \pm 0.08$ & 34.52 & 9.9 \\
\hline & 100 & $127.8 \pm 14.6$ & $0.63 \pm 0.10$ & 34.57 & 9.5 \\
\hline & 200 & $116.4 \pm 20.8$ & $0.48 \pm 0.11$ & 34.50 & 8.4 \\
\hline & 400 & $41.3 \pm 10.5$ & $0.67 \pm 0.08$ & 34.42 & 7.5 \\
\hline & 600 & $9.8 \pm 12.5$ & $0.18 \pm 0.08$ & 34.35 & 6.6 \\
\hline & 800 & $-112.0 \pm 53.2$ & $0.15 \pm 0.09$ & 34.33 & 5.2 \\
\hline & 1000 & $-82.7 \pm 9.4$ & $0.11 \pm 0.08$ & 34.35 & 4.0 \\
\hline \multirow[t]{8}{*}{$47.0^{\circ} \mathrm{S}$} & 10 & $-4.6 \pm 34.4$ & $0.57 \pm 0.10$ & 34.48 & 10.6 \\
\hline & 50 & $40.2 \pm 27.1$ & $0.70 \pm 0.09$ & 34.45 & 9.6 \\
\hline & 100 & $-9.8 \pm 31.2$ & $0.69 \pm 0.09$ & 34.44 & 9.0 \\
\hline & 140 & $57.9 \pm 22.9$ & $0.67 \pm 0.05$ & 34.52 & 9.1 \\
\hline & 250 & $46.5 \pm 21.9$ & $0.70 \pm 0.09$ & 34.44 & 7.8 \\
\hline & 500 & $25.7 \pm 17.7$ & $0.52 \pm 0.09$ & 34.38 & 7.0 \\
\hline & 750 & $35.0 \pm 19.8$ & $0.25 \pm 0.08$ & 34.33 & 5.4 \\
\hline & 1000 & $38.1 \pm 19.8$ & $0.00 \pm 0.09$ & 34.34 & 3.9 \\
\hline
\end{tabular}




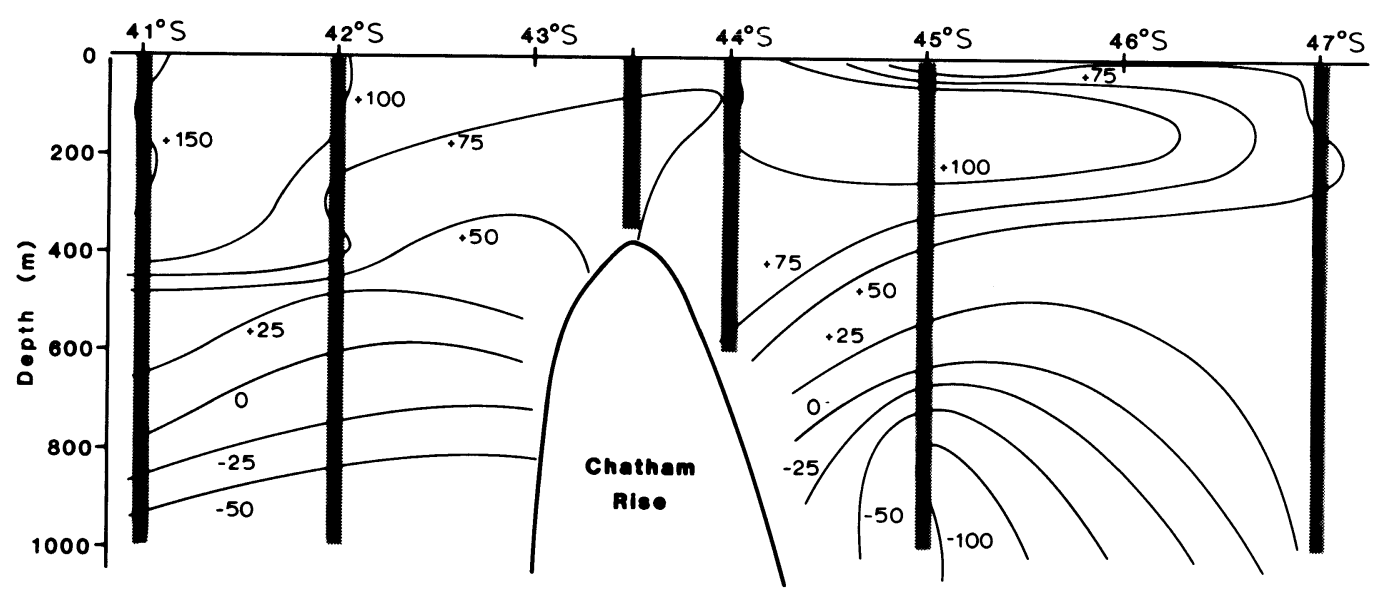

\section{Cruise $2013 \Delta{ }^{14} \mathrm{C}$ contours}

Fig. 3. Contours of $\Delta^{14} \mathrm{C}$, measured in parts per mil, from samples collected in November 1987

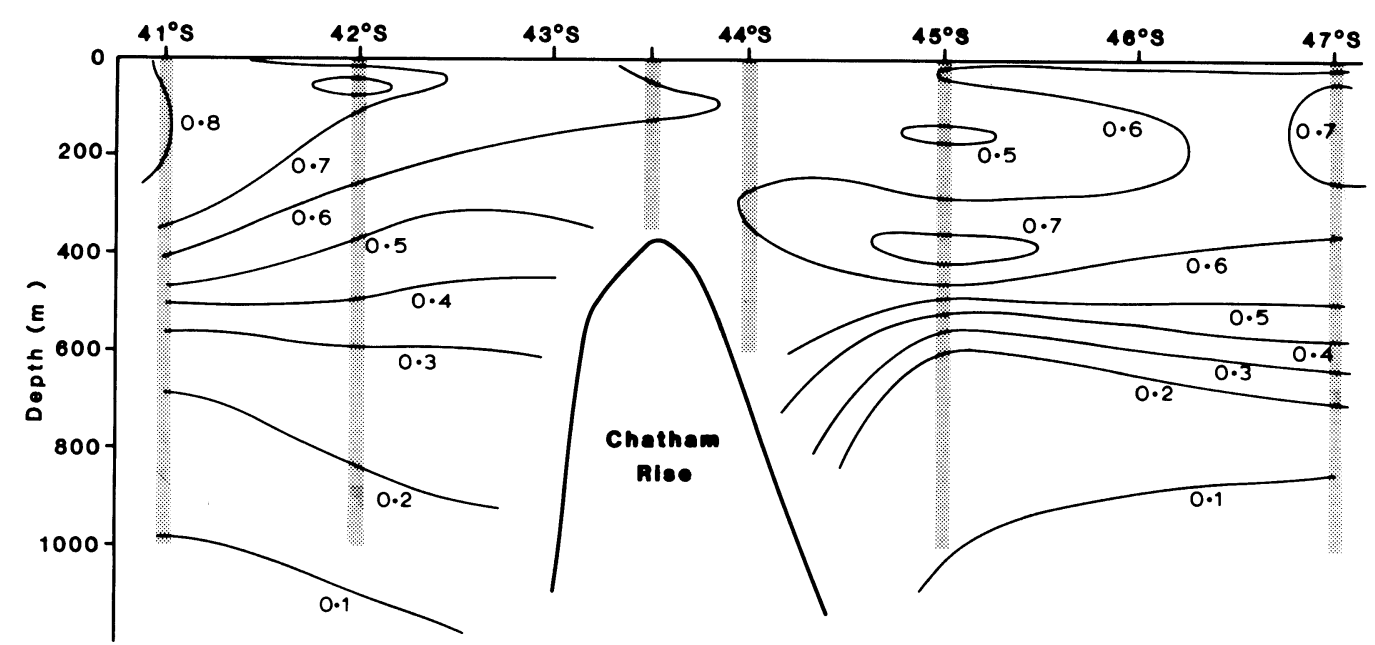

Cruise 2013 Tritium contours

Fig. 4. Contours of tritium concentrations measured in tritium units, from samples collected in November 1987

arising from a northward flow in the mixed layer overlaying a southward and upward flow below the mixed layer. The similarity of the structure of the salinity distributions in the present work (Fig. 5) to the ${ }^{14} \mathrm{C}$ and tritium distributions makes it reasonable to identify the isotopic distributions with the structure discussed by Heath, and arising by the same mechanism. The magnitudes of the ${ }^{14} \mathrm{C}$ and salinity anomalies are very different, however. The increase in salinity across the tongue is $c a$. $0.1 \%$ in $34.5 \%$, an increase of $0.3 \%$, whereas the ${ }^{14} \mathrm{C}$ increases from $+50 \%$ near the surface to ca. $+100 \%$ at $200 \mathrm{~m}$, an increase of $5 \%$ in total concentration. 


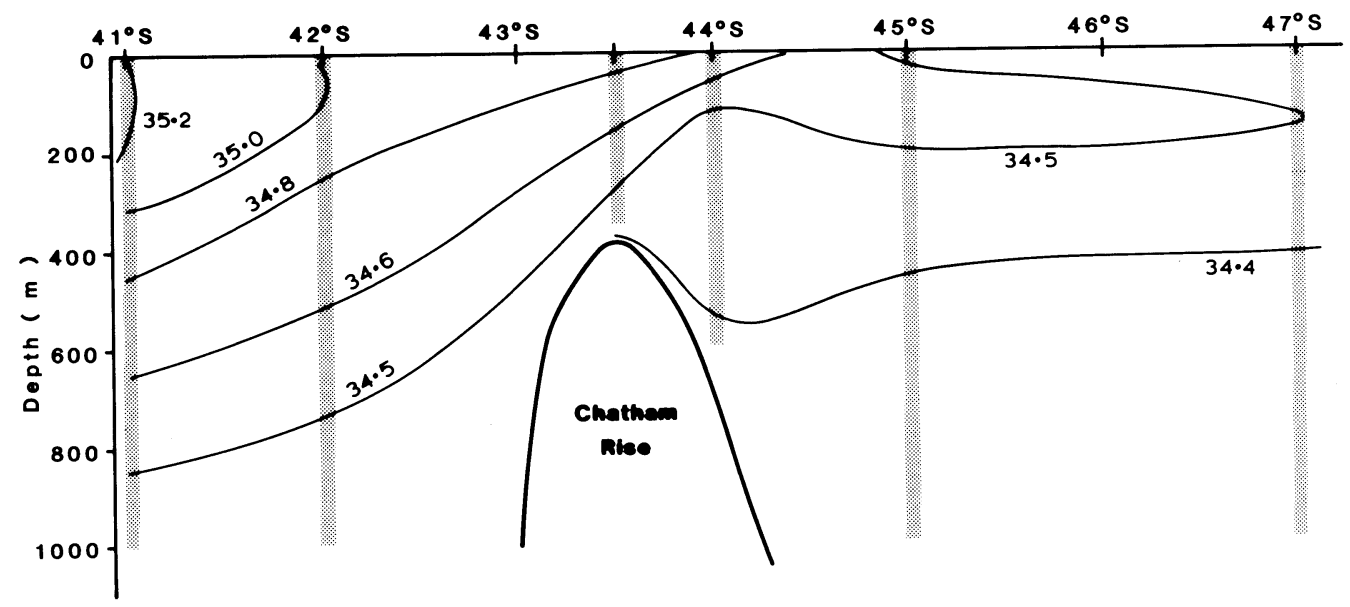

Cruise 2013 Salinity contours

Fig. 5. Contours of salinity, measured in $\mathrm{gm} \mathrm{kg}^{-1}$, from samples collected in November 1987

Another feature of Figure 3 is the ${ }^{14} \mathrm{C}$ depth profile at the extreme southern cast at $47^{\circ} \mathrm{S}$. Below $200 \mathrm{~m}$, the $\Delta^{14} \mathrm{C}$ is almost constant at $\mathrm{ca} .+30 \%$ down to the maximum depth sampled, $1000 \mathrm{~m}$. This is quite unlike typical mid-ocean depth profiles (e.g., Broecker et al. 1985), and indicates downward vertical transport to at least $1000 \mathrm{~m}$. This observation is consistent with observations of the Chatham Rise region (Heath 1982). Accepting this interpretation of the ${ }^{14} \mathrm{C}$ profile, comparison with the tritium data makes it possible to deduce the time required for the vertical transport. A positive $\Delta^{14} \mathrm{C}$ value means that the ${ }^{14} \mathrm{C}$ that is observed is, in fact, bomb carbon, and so the water must have been exposed at the ocean surface since $c a$. 1955. On the other hand, the tritium data (Fig. 4) show that the tritium activity at $1000 \mathrm{~m}$ in this region has declined relative to the surface by a factor of 6 , corresponding to roughly 2.5 half-lives, or 30 years. Because the tritium also enters the ocean at the surface, the exposure must have occurred $c a$. 1960. The elapsed times since exposure implied by the radioisotope measurements are in good agreement, and result in a mean vertical transport velocity of $c a .1 \times 10^{-4} \mathrm{~cm} \mathrm{~s}^{-1}$. This rather simple approach accounts for the observed profiles in terms of water transport, and neglects mixing. The justification for this is based on the ${ }^{14} \mathrm{C}$ profile; whereas the tritium profile could be due to mixing, one would expect the ${ }^{14} \mathrm{C}$ profile to be affected in the same way and not be almost constant. Just south of the Rise, at latitude $45^{\circ} \mathrm{S}$, there seems to be a core of older water rising up from below $1000 \mathrm{~m}$. This is interpreted as Antarctic Intermediate Water that is low in ${ }^{14} \mathrm{C}$ welling up against the southern flank of the Chatham Rise.

Radiocarbon, tritium and salinity distributions measured on Cruise 2028 are plotted in Figures 6-8 and the data are listed in Table 2 . The ${ }^{14} \mathrm{C}$ data are more sparse for this set, but serve to verify the main details of the previous measurements. For these samples the inorganic carbon yield was measured in units of $\mathrm{mg}$ carbon liter ${ }^{-1}$. The ${ }^{14} \mathrm{C}$ concentration, $\mathrm{c}$, can be calculated, using the formula

$$
c=\mathrm{yN}_{\mathrm{A}}\left(1+\frac{\delta^{14} \mathrm{C}}{1000}\right) \times 1.176 \times 10^{-12} \frac{\text { atoms }}{\text { liter }}
$$

where $y$ is the yield of carbon in moles liter ${ }^{-1}$ and $N_{A}$ is Avogadro's number. Because we wish to obtain the absolute ${ }^{14} \mathrm{C}$ concentration in the water, it is inappropriate to include a fractionation cor- 


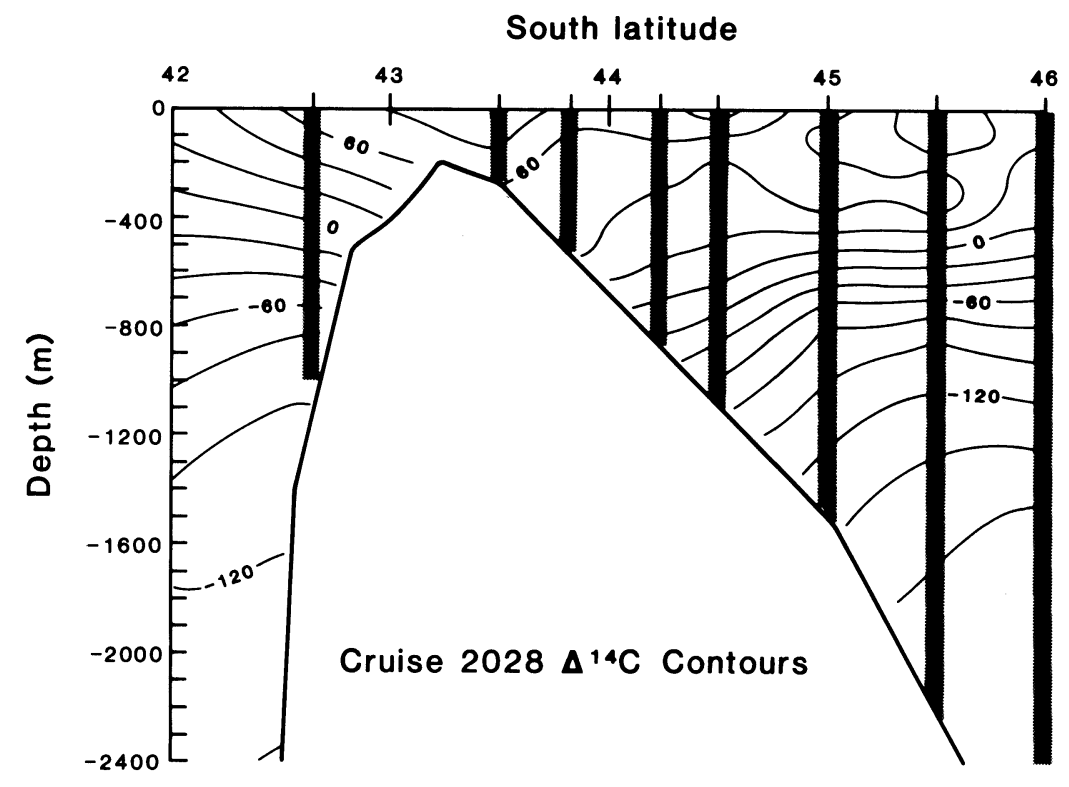

Fig. 6. Contours of $\Delta^{14} \mathrm{C}$, measured in parts per mil, from samples collected in July 1989

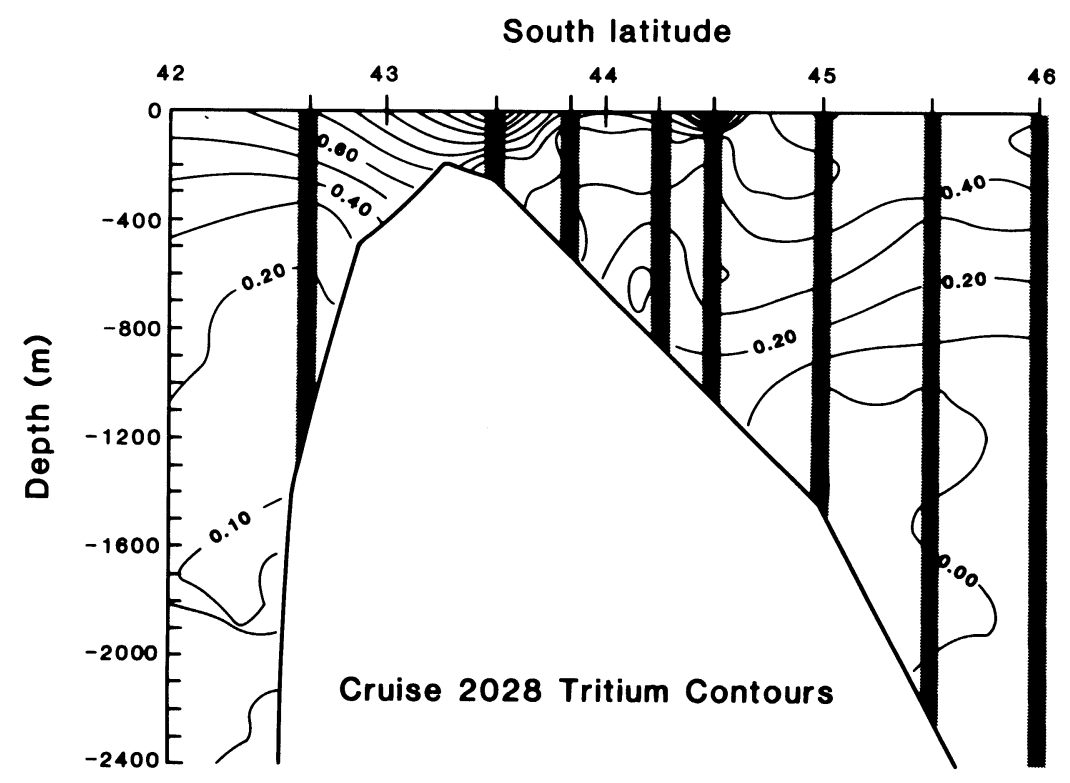

Fig. 7. Contours of tritium, measured in tritium units, from samples collected in July 1989 
TABLE 2. Data for Samples Collected on RV Rapuhia Cruise 2028 July 1989

\begin{tabular}{|c|c|c|c|c|c|c|}
\hline Latitude & $\begin{array}{l}\text { Depth } \\
\text { (m) }\end{array}$ & $\begin{array}{l}\Delta^{14} \mathrm{C} \\
(\% o)\end{array}$ & $\begin{array}{c}\text { Tritium } \\
\text { (TU) }\end{array}$ & $\begin{array}{c}\text { Salinity } \\
(\% o)\end{array}$ & $\begin{array}{l}\text { Carbon yield } \\
\text { mg liter }^{-1} \\
( \pm 5 \%)\end{array}$ & $\begin{array}{c}\text { Total }{ }^{14} \mathrm{C} \\
10^{9} \text { atoms liter }\end{array}$ \\
\hline \multirow[t]{3}{*}{$42.7^{\circ} \mathrm{S}$} & 3 & $73.5 \pm 9.0$ & $0.71 \pm 0.08$ & & 21.4 & $1.43 \pm 0.07$ \\
\hline & 397 & $3.9 \pm 11.3$ & $0.22 \pm 0.06$ & 34.66 & & \\
\hline & 900 & $-93.8 \pm 8.6$ & & 34.46 & 27.0 & $1.52 \pm 0.07$ \\
\hline \multirow[t]{2}{*}{$43.5^{\circ} \mathrm{S}$} & 3 & $96.1 \pm 13.0$ & $1.43 \pm 0.09$ & 34.70 & 24.2 & $1.65 \pm 0.08$ \\
\hline & 200 & $73.9 \pm 7.9$ & $0.44 \pm 0.08$ & 34.73 & 23.7 & $1.58 \pm 0.08$ \\
\hline \multirow[t]{5}{*}{$43.8^{\circ} \mathrm{S}$} & 100 & $56.7 \pm 17.7$ & $0.36 \pm 0.07$ & 34.34 & 24.4 & $1.60 \pm 0.08$ \\
\hline & 150 & $49.1 \pm 10.7$ & $0.60 \pm 0.07$ & 34.38 & 26.6 & $1.74 \pm 0.08$ \\
\hline & 250 & $34.2 \pm 10.2$ & $0.39 \pm 0.07$ & 34.52 & 26.3 & $1.69 \pm 0.08$ \\
\hline & 350 & $47.2 \pm 10.8$ & & 34.41 & 25.1 & $1.63 \pm 0.08$ \\
\hline & 520 & $47.1 \pm 11.3$ & $0.48 \pm 0.07$ & 34.39 & 26.1 & $1.69 \pm 0.08$ \\
\hline \multirow[t]{10}{*}{$44.2^{\circ} \mathrm{S}$} & 3 & & $0.70 \pm 0.09$ & 34.27 & & \\
\hline & 75 & & $0.33 \pm 0.05$ & 34.28 & & \\
\hline & 125 & & $0.55 \pm 0.06$ & 34.39 & & \\
\hline & 175 & & $0.41 \pm 0.06$ & 34.54 & & \\
\hline & 200 & & $0.55 \pm 0.07$ & 34.47 & & \\
\hline & 300 & & $0.41 \pm 0.06$ & 34.44 & & \\
\hline & 400 & & $0.36 \pm 0.05$ & 34.44 & & \\
\hline & 600 & & $0.15 \pm 0.05$ & 34.41 & & \\
\hline & 800 & & $0.23 \pm 0.05$ & 34.37 & & \\
\hline & 1000 & & $0.14 \pm 0.06$ & 34.37 & & \\
\hline \multirow[t]{4}{*}{$44.5^{\circ} \mathrm{S}$} & 5 & $91.7 \pm 12.6$ & $1.29 \pm 0.09$ & 34.26 & 24.6 & $1.67 \pm 0.08$ \\
\hline & 160 & $39.5 \pm 9.8$ & $0.48 \pm 0.07$ & 34.49 & 26.3 & $1.69 \pm 0.08$ \\
\hline & 598 & $9.1 \pm 13.2$ & $0.43 \pm 0.08$ & 34.44 & 25.0 & $1.57 \pm 0.08$ \\
\hline & 1268 & $-94.5 \pm 12.7$ & $0.14 \pm 0.08$ & 34.44 & 27.3 & $1.54 \pm 0.08$ \\
\hline \multirow[t]{5}{*}{$45.0^{\circ} \mathrm{S}$} & 5 & $52.1 \pm 10.3$ & $0.37 \pm 0.06$ & 34.29 & 25.8 & $1.68 \pm 0.08$ \\
\hline & 151 & $14.7 \pm 9.1$ & $0.53 \pm 0.07$ & 34.39 & 24.5 & $1.55 \pm 0.07$ \\
\hline & 250 & $71.3 \pm 9.3$ & $0.52 \pm 0.07$ & 34.38 & 22.9 & $1.53 \pm 0.07$ \\
\hline & 750 & $-74.2 \pm 10.1$ & $0.24 \pm 0.06$ & 34.34 & 27.5 & $1.58 \pm 0.08$ \\
\hline & 1800 & $-149.3 \pm 10.2$ & $0.00 \pm 0.06$ & 34.71 & 28.8 & $1.53 \pm 0.07$ \\
\hline \multirow[t]{6}{*}{$45.5^{\circ} \mathrm{S}$} & 2 & $4.0 \pm 9.3$ & $0.46 \pm 0.06$ & 34.24 & 25.4 & $1.59 \pm 0.08$ \\
\hline & 150 & $-5.3 \pm 9.5$ & $0.48 \pm 0.07$ & 34.39 & 27.1 & $1.67 \pm 0.08$ \\
\hline & 250 & $74.4 \pm 12.3$ & $0.47 \pm 0.08$ & 34.38 & 26.6 & $1.78 \pm 0.09$ \\
\hline & 800 & $-92.7 \pm 9.0$ & $0.13 \pm 0.07$ & 34.35 & 25.8 & $1.45 \pm 0.07$ \\
\hline & 1500 & $-153.5 \pm 8.7$ & $0.01 \pm 0.07$ & 34.61 & 28.1 & $1.47 \pm 0.07$ \\
\hline & 2400 & $-181.6 \pm 13.0$ & $0.18 \pm 0.06$ & 34.80 & 26.8 & $1.37 \pm 0.07$ \\
\hline \multirow[t]{6}{*}{$46.0^{\circ} \mathrm{S}$} & 3 & $44.9 \pm 12.6$ & $0.42 \pm 0.06$ & 34.22 & 25.0 & $1.62 \pm 0.08$ \\
\hline & 150 & $12.7 \pm 8.8$ & $0.41 \pm 0.07$ & 34.37 & 26.8 & $1.68 \pm 0.08$ \\
\hline & 400 & $5.2 \pm 10.5$ & $0.31 \pm 0.08$ & 34.36 & 26.5 & $1.65 \pm 0.08$ \\
\hline & 700 & $-63.2 \pm 9.7$ & $0.16 \pm 0.05$ & 34.33 & 25.8 & $1.51 \pm 0.07$ \\
\hline & 1500 & $-165.6 \pm 9.1$ & $0.04 \pm 0.06$ & 34.60 & 27.1 & $1.41 \pm 0.07$ \\
\hline & 2400 & $-157.0 \pm 15.3$ & $0.15 \pm 0.06$ & 34.79 & 26.4 & $1.38 \pm 0.07$ \\
\hline
\end{tabular}


TABLE 3. Concentration of ${ }^{14} \mathrm{C}$ averaged for three depth intervals.

Data from samples collected in July 1989

\begin{tabular}{cc}
\hline & ${ }^{14} \mathrm{C}$ concentration \\
$10^{9}$ atoms liter & -1 \\
\hline $0-200$ & $1.63 \pm 0.07$ \\
$200-700$ & $1.63 \pm 0.08$ \\
$>1000$ & $1.47 \pm 0.07$ \\
\hline
\end{tabular}

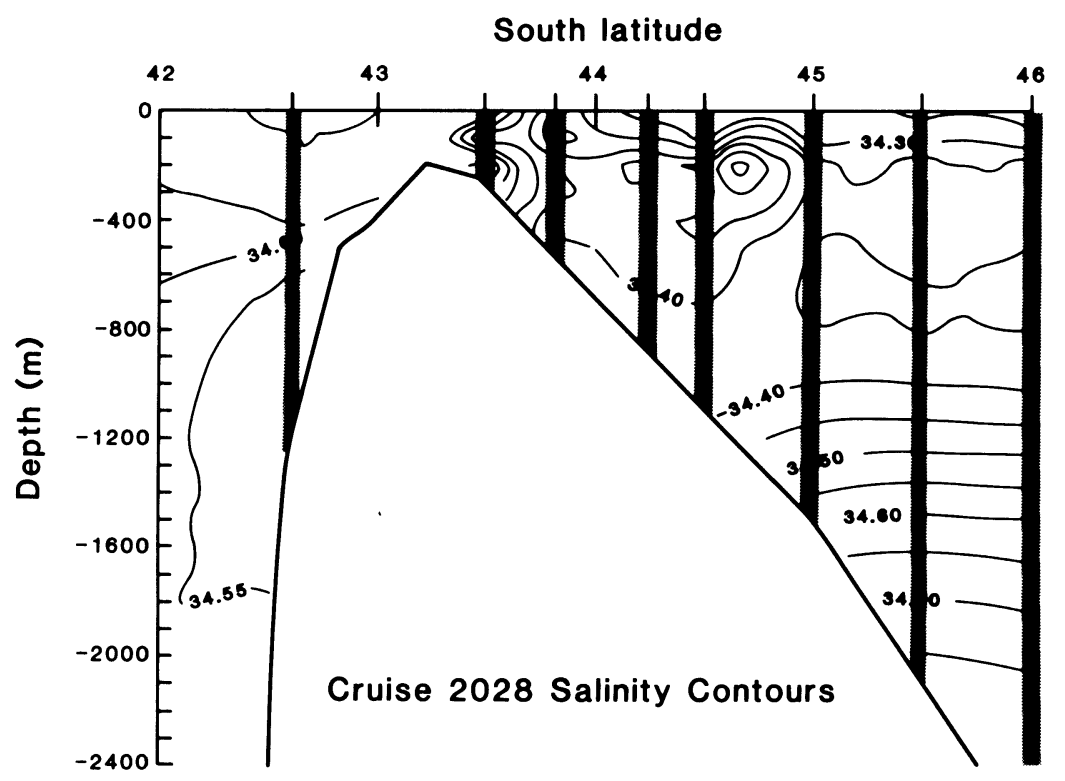

Fig. 8. Contours of salinity, measured in $\mathrm{gm} \mathrm{kg}^{-1}$, from samples collected in July 1989

rection in the calculation. For this reason, the expression uses $\delta^{14} \mathrm{C}$ (Stuiver \& Polach 1977), which is the ${ }^{14} \mathrm{C}$ enrichment uncorrected for fractionation. The ${ }^{14} \mathrm{C}$ concentration so obtained is shown in units of $10^{9}{ }^{14} \mathrm{C}$ atoms liter ${ }^{-1}$ in Table 2 . The mean ${ }^{14} \mathrm{C}$ concentration with its standard deviation is $(1.58 \pm 0.10) \times 10^{9}$ atoms liter ${ }^{-1}$, averaged over all samples. In Table 3 , the concentration is averaged for three depth ranges, showing that it is essentially constant down to $c a .700 \mathrm{~m}$, and falls off at greater depths.

The main features of Figure 6 are the less well-defined structure at the STC and the repeated presence of the subsurface tongue extending south of the Chatham Rise, although this time the increase in $\Delta^{14} \mathrm{C}$ across the tongue is not so pronounced. These differences probably reflect seasonal effects, as the first set of samples was collected in early (southern) summer and the second set in mid-winter. The tongue appears also in the tritium and salinity data, once again with lower intensity. The latitude range covered by the second set of samples did not extend sufficiently far south to be able to check the almost uniform ${ }^{14} \mathrm{C}$ depth profile observed before at $47^{\circ} \mathrm{S}$. However, the upwelling of older Antarctic Intermediate Water on the southern flank of the rise is again visible. 


\section{CONCLUSIONS}

The main aim of this investigation was to see if measurements of ${ }^{14} \mathrm{C}$ and tritium could provide information about the circulation patterns in the vicinity of the Chatham Rise. The data show that the presence of the STC is reflected in the radioisotope distributions, and ${ }^{14} \mathrm{C}$, in particular, is a sensitive probe for detecting the tongue of subducted water that extends south of the STC. Also, the ${ }^{14} \mathrm{C}$ and tritium together indicate substantial mixing in a localized region around latitude $47^{\circ} \mathrm{S}$, and allow a time scale to be deduced for this process. One of the main motivations for studying ${ }^{14} \mathrm{C}$ in the oceans is to obtain information about the exchange of atmospheric $\mathrm{CO}_{2}$ between the atmosphere and the ocean surface waters. However, as the present work shows, in a region where the bathymetry plays a significant role in determining the circulation, the isotopic signal can become quite complex. Indeed, it is just this complexity that can provide the information about the local circulation patterns, but it also means that conclusions drawn about the transfer of ${ }^{14} \mathrm{C}$ from the atmosphere into the ocean are not likely to be typical of open ocean conditions.

\section{REFERENCES}

Broecker, W., Peng, T-H., Ostlund, G. and Stuiver, M. 1985 The distribution of bomb radiocarbon in the ocean. Journal of Geophysical Research 90(C4): 6953-6970.

Heath, R. 1976 Models of the diffusive-advective balance at the Subtropical Convergence. Deep-Sea Research 23: 1153-1164.

1981 Oceanic fronts around southern New Zealand. Deep-Sea Research 28A(6): 547-560.

1982 Physical oceanography of the waters over the Chatham Rise. NZOI Summary 18.

Sparks, R., Lowe, D. C., Dlugokencky, E. J., Drummond, G. W. and Brailsford, G. W. 1988 Method for the extraction of $\mathrm{CO}_{2}$ from seawater for ${ }^{14} \mathrm{C}$ analysis by AMS. Institute of Nuclear Sciences Internal Report INS-R-375.

Stuiver, M. and Polach, H. 1977 Discussion: Reporting of ${ }^{14} \mathrm{C}$ data. Radiocarbon 19(3): 355-363. 